\title{
The effect of heat treatment on degradability and microbial synthesis of protein in the rumen*
}

\author{
P. Lund ${ }^{1,3}$, M.R. Weisbjerg ${ }^{1}$ and T. Kristensen ${ }^{2}$ \\ ${ }^{1}$ Department of Animal Nutrition and Physiology, \\ ${ }^{2}$ Department of Agroecology, \\ Danish Institute of Agricultural Sciences, Research Centre Foulum \\ P.O. Box 50, DK-8830 Tjele, Denmark
}

\begin{abstract}
Effect of heat treatment (toasting) on protein degradability in the rumen was evaluated for four organic concentrates (field beans, soyabeans, blue lupin and peas) in simple cross-over experiments with rumen and intestinally fistulated cows. For soyabeans, field beans and blue lupin, heat treatment numerically increased duodenal flow of amino acid N (AAN) due to an increase in flow of undegraded feed AAN. For peas the increase in duodenal flow of undegraded feed AAN was counterbalanced by a similar decrease in microbial AAN synthesis, probably due to sub-optimal rumen ammonia concentrations. Heat treatment had no overall effect on microbial efficiency.
\end{abstract}

KEY WORDS: toasting, amino acids, field bean, soyabean, blue lupin, peas

\section{INTRODUCTION}

Organic milk production constitutes about $10 \%$ of the milk production in Denmark. Focus has been on obtaining a 100\% organic feeding and an increase in the proportion of home-grown feeds. One of the major problems has been to secure the cows a sufficient level of metabolizable protein. Degradation of protein in the rumen should therefore be restricted to what is necessary for an effective fermentation. Due to reactions between $\varepsilon$-amino groups and reducing sugars, heat treatment has the potential to decrease rumen protein degradability and increase supply of metabolizable protein. Increasing the metabolizable protein of feed origin can however reduce the biological value of the metabolizable protein, due

\footnotetext{
${ }^{*}$ DLG is acknowledged for supply and processing of the four concentrates

${ }^{3}$ Corresponding author: e-mail: Peter.Lund@agrsci.dk
} 
to a changed composition of the amino acid supply to the intestine. The objective was therefore to determine the effects of heat treatment on protein value of organic protein supplements.

\section{MATERIAL AND METHODS}

Italian organic soyabeans and Danish organic peas, field beans and blue lupin were toasted at $140^{\circ} \mathrm{C}$ for $90-120 \mathrm{sec}$. Effect of heat treatment on protein value was investigated in four separate simple cross-over experiments, one for each feed. The over-all experiment was designed to be a screening for overall effects of heat treatment on protein value. Cross-over experiments were run in pairs, and two rumen and duodenum fistulated cows were used in each experiment. The four cows averaged 270 days in milk $\left(19.3 \mathrm{kgd}^{-1}\right)$ and had an average weight of $650 \mathrm{~kg}$ at the onset. Cows were fed $5 \mathrm{~kg}$ of the concentrates per day, divided into two feedings $(07.30,17.00)$, and fed a conventional first cut grass-clover silage ad libitum. The first ten days were used for adaptation and the last five days for collection of samples. Based on 12 samples of duodenal chyme, the protocol was arranged to give representative pooled samples of the diurnal flow. Chromium oxide $(2 \times 10.0 \mathrm{~g}$ per day) was administrated via the rumen cannula at feedings, and used as flow marker. Rumen liquid associated bacteria were isolated by sequential centrifugation. Microbial synthesis of amino acid nitrogen (AAN) was determined based on purine: AAN ratio in isolated bacteria and in duodenal chyme. Microbial efficiency was calculated based on apparent rumen digested organic matter (OM). Unfortunately one of the bacterial samples was lost for toasted soyabeans, and therefore no statistical analysis was performed on microbial AAN synthesis and efficiency for this feed. Rumen outflow of undegraded feed AAN was calculated based on duodenal AAN flow subtracted microbial AAN and endogenous AAN. Endogenous AAN $\left(\mathrm{g} \mathrm{d}^{-1}\right)$ was estimated as $4.1 \times$ DM intake $(\mathrm{kg})-1.8$ (Larsen et al., 2000). The effect of heat treatment on effective protein degradability and total tract digestibility was evaluated using nylon bag methods. Protein degradability corrected for particulate loss during washing was calculated as described by Hvelplund and Weisbjerg (2000). Conventional methods were used for chemical analysis and the statistical analysis was done within each experiment using GLM in SAS 8.e.

\section{RESULTS}

Heat treatment slightly reduces lysine in field beans, soyabeans and blue lupin, but had no negative effect on amino acid availability expressed as ADF-N. Total tract in situ digestibility (mobile nylon bag) seemed not to be negatively affected by heat treatment (data now shown). Due to the few observations, there was no significant effect on AAN flows or microbial efficiency. Endogenous AAN was fairly constant due to the constant DM intake. Microbial AAN 
synthesis based on purines varied from $91 \mathrm{~g} \mathrm{~d}^{-1}$ for heat treated soyabeans to $151 \mathrm{~g} \mathrm{~d}^{-1}$ for untreated field beans. For field beans, soyabeans and especially peas, microbial synthesis was numerically decreased when feeds were heat treated. The increased duodenal AAN flow (field beans, soyabeans and blue lupin) was therefore primarily due to a numerical increase in duodenal flow of undegraded feed AAN. Microbial efficiency was on average $21 \mathrm{~g}$ per $\mathrm{kg}$ rumen apparently digested OM. Protein degradability (PD) of the ration based on in situ degradation of the individual feeds was higher than based on duodenal AAN flow subtracted endogenous and microbial AAN. Both methods predicted a minor effect of heat treatment on PD for peas and a major effect for soyabeans and blue lupin, whereas the in vivo method predicted an higher effect for field beans than the in situ method (Table 1).

Table 1. Chemical composition (\% DM), DM intake ( $\mathrm{kg})$, duodenal flow $\left(\mathrm{g} \mathrm{d}^{-1}\right)$ of AAN, microbial efficiency $\left(\mathrm{g} \mathrm{kg}^{-1}\right)$ and rumen in situ and in vivo protein degradability of the ration, \%

\begin{tabular}{|c|c|c|c|c|c|c|c|c|}
\hline & \multicolumn{2}{|c|}{ Field beans } & \multicolumn{2}{|c|}{ Soyabeans } & \multicolumn{2}{|c|}{ Blue lupin } & \multicolumn{2}{|c|}{ Peas } \\
\hline & control & heat & control & heat & control & heat & control & Heat \\
\hline Lysine & 2.08 & 1.97 & 2.47 & 2.43 & 1.57 & 1.48 & 1.62 & 1.62 \\
\hline Methionine & 0.23 & 0.22 & 0.53 & 0.54 & 0.19 & 0.18 & 0.22 & 0.22 \\
\hline Amino acids & 29.1 & 27.3 & 36.5 & 36.3 & 30.3 & 28.7 & 20.0 & 20.1 \\
\hline ADF-N, $\% \mathrm{~N}$ & 0.95 & 0.79 & 2.31 & 2.19 & 1.48 & 1.27 & 0.00 & 0.00 \\
\hline DM intake & 16.9 & 17.4 & 13.0 & 12.4 & 16.1 & 16.3 & 14.0 & 14.4 \\
\hline Duo. AAN & 323 & 352 & 289 & 336 & 320 & 370 & 282 & 271 \\
\hline -endo. AAN & 68 & 69 & 52 & 49 & 64 & 65 & 55 & 57 \\
\hline -micro. AAN & 151 & 137 & 98 & 91 & 137 & 144 & 136 & 110 \\
\hline -feed AAN & 104 & 145 & 139 & 167 & 119 & 162 & 90 & 103 \\
\hline Mic. Eff. & 21 & 20 & 20 & 27 & 21 & 24 & 25 & 17 \\
\hline In vivo $\mathrm{PD}$ & 58 & 47 & 51 & 43 & 55 & 43 & 52 & 47 \\
\hline In situ PD & 83 & 81 & 84 & 72 & 84 & 72 & 84 & 80 \\
\hline
\end{tabular}

Except for peas, processing seemed to have a positive effect on duodenal AAN flow (Figure 1A), especially for cows on soyabeans and blue lupin, where AAN flow increased with $47 \mathrm{~g} \mathrm{~d}^{-1}$ and $50 \mathrm{~g} \mathrm{~d}^{-1}$, respectively (Table 1). In no observations heat treatment resulted in a lower duodenal flow of undegraded feed AAN (Figure 1B), although the in-between cows variation was high. 

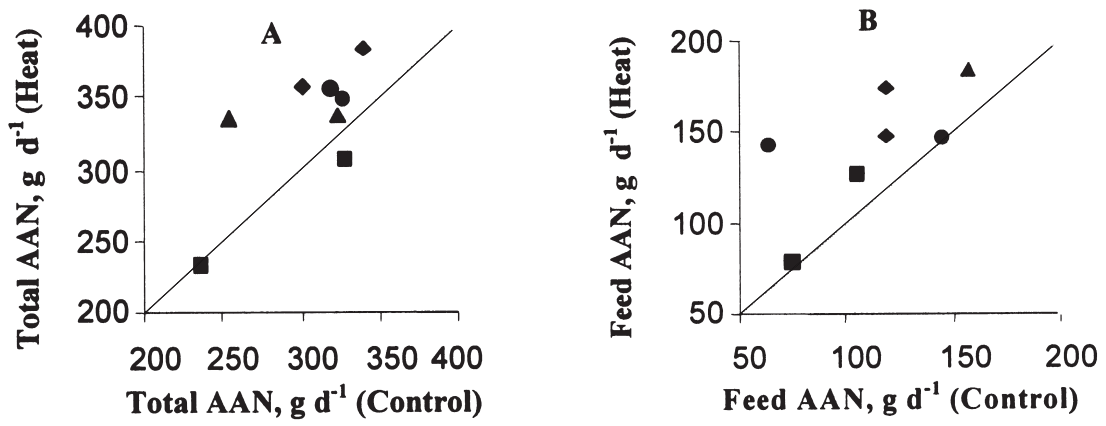

Figure 1. Comparison of duodenal AAN flow. (A) Total. (B) Undegraded feed AAN. Each data point represents two observations (Control vs Heat) on one cow (field beans: $\bullet$, soyabeans: $\boldsymbol{\Delta}$, blue lupin: $\diamond$, peas: $\mathbf{\square})$

\section{DISCUSSION}

Microbial efficiencies were similar to literature values, and the differences in the absolute values for PD between the in situ method and the in vivo method was therefore probably due to either an underestimation of endogenous AAN or an overestimation of in situ PD. For soyabeans, blue lupin and peas the in situ method predicted the same quantitative effect as the in vivo method, whereas for field beans the effect was smaller based on in situ PD than on the in vivo method. The in situ method can however be used to evaluate the effect of heat treatment on duodenal flow of undegraded feed AAN. Absence of a positive effect of processing of peas on duodenal AA flow was not due to absence of an effect on degradability, but due to a decrease in microbial synthesis, in agreement with low rumen ammonia concentrations in a major part of the day.

\section{CONCLUSIONS}

Although the statistical material is weak, this screening does indicate that heat treatment has the potential to improve the protein value of organic protein supplements. Toasting can increase duodenal flow of undegraded feed AAN, without hampering microbial AAN synthesis or intestinal digestibility, and thereby increase metabolizable protein.

\section{REFERENCES}

Hvelplund T., Weisbjerg M.R., 2000. In situ techniques for the estimation of protein degradability and postrumen availability. In: D.I. Givens, E. Owen, R.F.E. Axford, H.M. Omed (Editors). Forage Evaluation in Ruminant Nutrition. CABI Publishing, pp. 233-258

Larsen M., Madsen T.G., Weisbjerg M.R., Hvelplund T., Madsen J., 2000. Endogenous amino acid flow in the duodenum of dairy cows. Acta Agr. Scand., Sect. A, Anim. Sci. 50, 161-173 